\title{
The importance of corrosion resistance test of cannulas in the quality control of hypodermic needles
}

\author{
Michele Feitoza-Silva ${ }^{\circledR 1 *}$, Carolina Mesquita de Carvalho', Lívia Bretas Bittencourt ${ }^{1}$, \\ Katia Christina Leandro ${ }^{1}$, André Luis Gemal ${ }^{2}$
}

\begin{abstract}
${ }^{1}$ Chemistry Department, National Institute for Quality Control in Health, Fundação Oswaldo Cruz, Rio de Janeiro, Brasil, ${ }^{2}$ Chemistry Institute, Federal University of Rio de Janeiro, Rio de Janeiro, Brasil
\end{abstract}

\begin{abstract}
According to Anvisa risk rating, hypodermic needles offer medium risk to the user's health. This study discussed the importance of the corrosion resistance test in tubes of hypodermic needles, in the product quality control. A review of cannulas of hypodermic needles was carried out according to ISO 9626:2003 and 9259:1997 ABNT NBR. For the results evaluation, a scale which classifies the extent of corrosion was adjusted. 174 samples of PNI needles from 17 States and 9 different record holders were analyzed. According to the methodology of ISO 9626:2003, 100\% of the samples were considered satisfactory. However, in accordance with the methodology of ISO 9259:1997, 97.1\% of the samples were rejected. Irregularities can lead to impairment of product quality, resulting in risks to the consumer's health. Since 2011 the product has undergone certification, so it is necessary to reflect on the importance of corrosion resistance testing and mandatory certification for health monitoring.
\end{abstract}

Keywords: Corrosion. Hypodermic needles. Health surveillance.

\section{INTRODUCTION}

\section{Hypodermic needles}

The hypodermic needles are products intended for single use, which penetrate fully or partially into the body through its surface, being used primarily to inject drugs. According to the risk ranking adopted by Anvisa* (Agência Nacional de Vigilância Sanitária) [National Health Surveillance Agency], the hypodermic needles are classified as class II, i.e., they are considered as a product that offers medium risk to the user's health (Brasil, 2001).

It is a product considered as a strategic input for some of the programs from the Ministry of Health. Therefore, deviations in the quality of this product can affect a large number of people and have a major impact on public health (Brasil, 2006; Inmetro, 2009; Morais et al, 2010).

From a technical point of view, the needle is composed of a cannula connected to a plastic material

Correspondence to: M. Feitoza-Silva. Chemistry Department, National Institute for Quality Control in Health. Avenida Brasil, 4365, CEP 21040-900 - Manguinhos, Rio de Janeiro, Brasil. Phone: +552138655173 . E-mail: michele.feitoza@incqs.fiocruz.br known as barrel, which enables the coupling of the needle to the syringe. The cannula is a tube of stainless steel, with specific dimensions, which presents a perforating and sharp end, identified as bevel, as shown in Figure 1 (ABNT, 2010, 2011).

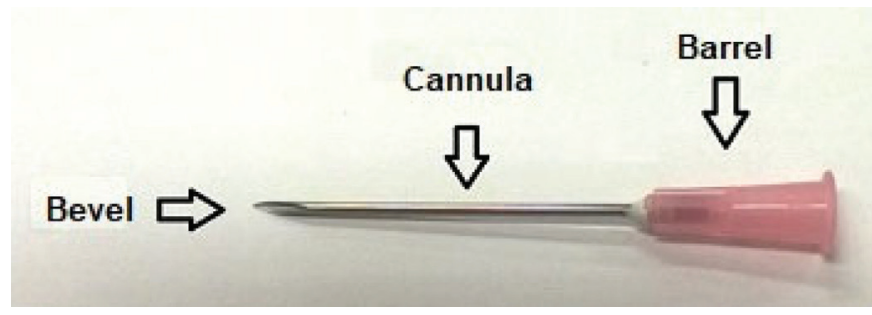

FIGURE 1 - Components of a hypodermic needle.

\section{Stainless steel and hypodermic needles}

The stainless steel is an alloy of iron with at least $12 \%$ of chromium. The presence of chromium is considered indispensable, because it allows the formation of a passive film, which is a thin layer of chromium oxide on the surface of the steel, making it impermeable and

*NOTE: Class I (low risk), II (medium risk), III (high risk) or IV (high risk). 
insoluble in a corrosive medium (Tebecherani, 2016). In addition to this metallic alloy features, other elements, in different percentages, have influence in its structure and properties. The reduction of carbon content and the addition of other elements such as molybdenum, nickel, silicon, aluminum, titanium and niobium can improve the corrosion resistance. These changes give rise to different types of this steel belonging to the 300 series (Bagatin et al, 2011; Carbó, 2011; Tebecherani, 2016).

Mechanical characteristics and resistance to corrosion turned the 304 steel, among those of the 300 series, into a stainless steel with the greatest diversity of applications, being used also in hospital equipment and pharmaceutical industries. Due to these characteristics, the Brazilian Association of Technical Standards (ABNT) published the Brazilian norms ABNT NBR ISO 9626:2003 and ABNT NBR 5601:2011, which determines that tubes for needles must be made of 304-type austenitic stainless-stee, which features in its composition 18 to $20 \%$ of chromium, 8 to $10 \%$ of nickel, small amounts of manganese and silicon, and a quantity of less than $0.1 \%$ of carbon (ABNT, 2003, 2010, 2011; Carbó, 2011).

As the hypodermic needles cannot have these characteristics in their external appearance, the resistance test of the cannula to corrosion evaluates whether the steel cannula has the necessary strength to withstand the corrosive attack, thus avoiding the partial or total destruction of a metallic alloy (ABNT, 1997, 2010; Iartelli, 2015; Inmetro, 2009).

These failures may result in a susceptibility of the cannula to corrosion, increasing the risk of a secondary injury, increased pain during insertion, in addition to enabling, sometimes, the growth of microorganisms, and increasing of needle's fragility, which can cause the risk of breakage during use.

Allergic and toxic reactions may occur in patients who often need to use that product or to those who are immunologically depressed (Inmetro, 2009).

\section{Sanitary legislation $\mathrm{x}$ national technical rules}

In order to standardize the requirements for needles, ABNT published the NBR 9259:1997 - Sterile single-use hypodermic needle, technical standard for the control of the quality of these products (ABNT, 1997, 2003).

The differences among the products supplied by different brands and the need for an update from the regulatory agencies, led to the publication of ABNT NBR ISO 9626, in 1999, which consists of the translation of the international regulation of the same number, showing the same requirements as recommended, including the new test method to evaluate the cannula resistance test to corrosion, using sodium chloride (ABNT, 2003).

Despite the established standards, a high number of notifications of technical complaints were sent to Anvisa on several problems presented by hypodermic needles. Based on this, Anvisa decided to coordinate a product analysis program for hypodermic needles and syringes, together with the National Institute of Metrology, Quality and Technology (Inmetro) and the National Institute of Quality Control in Health (INCQS), in order to analyze the quality of these products in relation to the risk of harm to the user's health (Inmetro, 2009).

The results obtained in the test of resistance of the cannulas to corrosion, carried out in agreement with the ABNT NBR 9259:1997, generated several criticisms by the manufacturers/importers, who demanded the invalidation of the results due to the use of the methodology preconized by the previous norm, and due to the non-evaluation of the alloy (Inmetro, 2009).

It is important to emphasize that these criticisms were not accepted in the study in 2009, since it is not necessary to perform a metal analysis to confirm the presence of corrosion, as this analysis would only identify if the steel is of the type specified in NBR 9259:1997, which does not avoid possible failures in the cannula production process. The composition of the correct stainless steel does not determine the corrosion resistance (Inmetro, 2009).

At the same time, Inmetro requested ABNT, in articulation with other entities in the sector, to revise ABNT NBR 9259:1997 standard, which resulted in the cancellation of this standard and the publication of ABNT NBR ISO 7864:2010 on sterile hypodermic needles for single use, which consists of the almost complete translation of ISO 7864:1993 (Brasil, 2001, Inmetro, 2009; ABNT, 2010).

Thus, the corrosion resistance test was carried out according to the methodology presented in ABNT 9626:2003, where the main alterations were the replacement of the citric acid solution with that of sodium chloride, immersion time and withdrawal of vision for final evaluation (Table I) (ABNT, 2010).

Despite the technical standard published by ABNT (2010), the first specific health legislation for the use of hypodermic and gingival needles appeared only in 2011 Anvisa's RDC $n^{\circ} .5 / 2011$, which established the minimum identity and quality requirements for these products and made the certification of compliance mandatory by the Brazilian Conformity Assessment System (SBAC). For this reason, it represents a regulatory framework (Brasil, 2011). 
The importance of corrosion resistance test of cannulas in the quality control of hypodermic needles

TABLE I - National standards with corrosion resistance test methodology

\begin{tabular}{cccc}
\hline STANDARD & SPECIFICITY & STATUS & METHODOLOGY TEST \\
\hline ABNT NBR 9259:1997 & Needle & $\begin{array}{c}\text { Replaced by } \\
\text { ABNT NBR ISO 7864:2010 }\end{array}$ & $\begin{array}{c}\text { Immersion in citric acid and } \\
\text { visual inspection with increase }\end{array}$ \\
\hline ABNT NBR ISO 9626:2003 & Needle tubing & In force & $\begin{array}{c}\text { Immersion in sodium chloride } \\
\text { and visual inspection without } \\
\text { increase }\end{array}$ \\
\hline ABNT NBR ISO 7864:2010 & Needle & In force & $\begin{array}{c}\text { Suggests methodology of } \\
\text { ABNT NBR ISO 9626:2003 }\end{array}$ \\
\hline
\end{tabular}

In 2011, there was also the publication of Ordinance $\mathrm{n}^{0} 501$ (Inmetro), which also has great regulatory importance, as it determined the compulsory requirements for conformity assessment for hypodermic needles, to be performed by the Certification Body of Product accredited by Inmetro. The conformity assessment demonstrates the importance of specific regulations for products that are strategic inputs to SUS (Brazilian Universal Healthcare Program) and that have many problems in the post-use context (Inmetro, 2011).

However, despite this determination of RDC $n^{\circ}$ $5 / 2011$, Ordinance/Inmetro $n^{\circ} 501 / 2011$ did not include this test among the analyzes carried out to evaluate the product's conformity, indicating that compulsory certification, despite contributing to the monitoring in the post-use, does not guarantee health quality, and constant surveillance is required. This deserves attention, in view of the nonconformity obtained in this test in the Product Analysis Program, and the failures that can occur in the tube manufacturing process, even with the use of appropriate stainless steel (ABNT, 2011; Inmetro, 2009; Inmetro, 2011).

Based on these considerations, it was decided to perform a comparison between the two methodologies that mainly differ by the use of expanded vision after the use of corrosive solution.

\section{EXPERIMENTAL}

\section{Experimental planning of cannula corrosion resistance tests}

174 samples of hypodermic needles were used in the study, all with seal of certification of metrology by Inmetro and acquired by the Brazilian Universal Healthcare Program. The sampling had national character (with the participation of 17 States). These samples were separated randomly into two groups of five units of the same batch and initially 5 tubes of each batch were analyzed as recommended in Annex E, from ABNT NBR ISO 9626:2003 regulation. The samples were placed in a glass container with a solution of sodium chloride 0.5 mol. $L^{-1}$ at $(23 \pm 2)^{\circ} \mathrm{C}$, so that approximately half the length of the tube of the needle was immersed for 7 hours \pm 5 minutes. After this period, they were removed and taken to drying through evaporation. Under proper lighting, a visual inspection of the cannula was performed, where the half immersed and not immersed halves were compared to identify signs of corrosion.

In a second moment, the other 5 tubes of each batch were analyzed according to that recommended in item 5.5 from ABNT NBR 9259:1997 regulation. The samples were immersed in a solution of citric acid 10\% and kept at room temperature for 5 hours in a neutral glass beaker. Then, they were removed and boiled in distilled water for 30 minutes. After this period, they were immersed in distilled water for 48 hours at room temperature, in a glass beaker, and subsequently dried through evaporation. Under proper lighting and seven times magnification, the visual inspection was performed using a stereomicroscope with zoom (Micronal/Olimpus - Model SZ-111-BR-SIT) to verify the existence of corrosion on the cannula surface.

\section{Criteria for the results evaluation}

Each unit was observed independently by two analysts. The individual notes were recorded in a spreadsheet of results, composed with the identification number of each unit assessed. The samples that showed no blemishes or signs of corrosion, as well as had a smooth surface without harshness or holes, were considered satisfactory. The samples that showed corrosion in at least one of the five units evaluated were considered unsatisfactory. For the evaluation of the results, it was identified the presence/absence of signs of corrosion. It was also used an adaptation of the scale of Akazawa et al. (2005), which classifies the corrosive damage to the steel into two categories based on the observation of the surface of the cannula (Table II). In addition, it was established the 
criteria to be checked in each category to ensure a standard at the conclusion of the test.

TABLE II - Classification of the corrosion degree

\begin{tabular}{cc}
\hline DEGREE & NOTE \\
\hline Corrosion degree 0 & Absence of corrosion \\
Corrosion degree 1 & Discoloration of the surface \\
Corrosion degree 2 & Superficial loss of material \\
\hline
\end{tabular}

\section{RESULTS AND DISCUSSION}

\section{Test of corrosion resistance of the cannula according to ABNT NBR ISO 9626:2003 standard}

The registries of needles and syringes were regulated only by RDC $185 / 2001$. In 2011 , the publication of specific regulations pointed to compulsory metrological certification for these products. In view of the history of nonconformities generated by the Product Analysis Program, created by Inmetro, Anvisa and INCQS, and with the certification implemented in the country, the INCQS considered it important to evaluate the quality of hypodermic needles and syringes available to the population (Brasil, 2011; Inmetro, 2009).

For this evaluation, INCQS accomplished a partnership with the National Immunization Program (PNI) as, due to being a program of national scope, it meets all age groups and social classes, while also being able to provide samples of needle batches used in practically all over Brazil.

The immersion test had the purpose of evaluating the high stability of the passive film that gives the steel the resistance to corrosion. Despite of the high resistance to corrosion, stainless austenitic steels are susceptible to corrosive action promoted by the adsorption of anions of chloride in the passive film (Giordani, Ferreira, Balancin, 2007).

ABNT NBR ISO 9626:2003 recommends that the half portion that was immersed must be compared with the half portion not immersed, in order to identify signs of corrosion, but the non-immersed half portion may show signs of corrosion resulting from the production process, and regardless of having originated in the test or during manufacturing, the presence of corrosion is considered a nonconformity. Thus, it is suggested that the method with partial immersion was insufficient to assess the presence of corrosion, bearing in mind that the material of the cannula is not perfectly homogeneous (Iartelli, 2015; Inmetro, 2009).

Upon evaluating the results of the cannula to corrosion, the cannula showed no signs of corrosion and was considered $100 \%$ satisfactory.

\section{Test of cannula resistance to corrosion according to the methodology of ABNT NBR ISO 9259:1997 regulation}

Although RDC n ${ }^{\circ}$ 5/2011 determines that the cannula is to be analyzed by ABNT NBR ISO 9626:2003 methodology, this regulation is not specific to the finished product. Therefore, it was also decided to analyze the samples according to the methodology described in ABNT NBR 9259:1997 to compare the results, because although it was canceled by ABNT, this standard presented the methodology previously used to evaluate the corrosion resistance in the finished product.

174 samples were obtained from 9 different registration holders, being that 169 samples failed in the cannula resistance test to corrosion, i.e., $97.1 \%$ of the samples of hypodermic needles showed corrosive damage (Graph 1).

According to Graph 1, brands A and E showed the

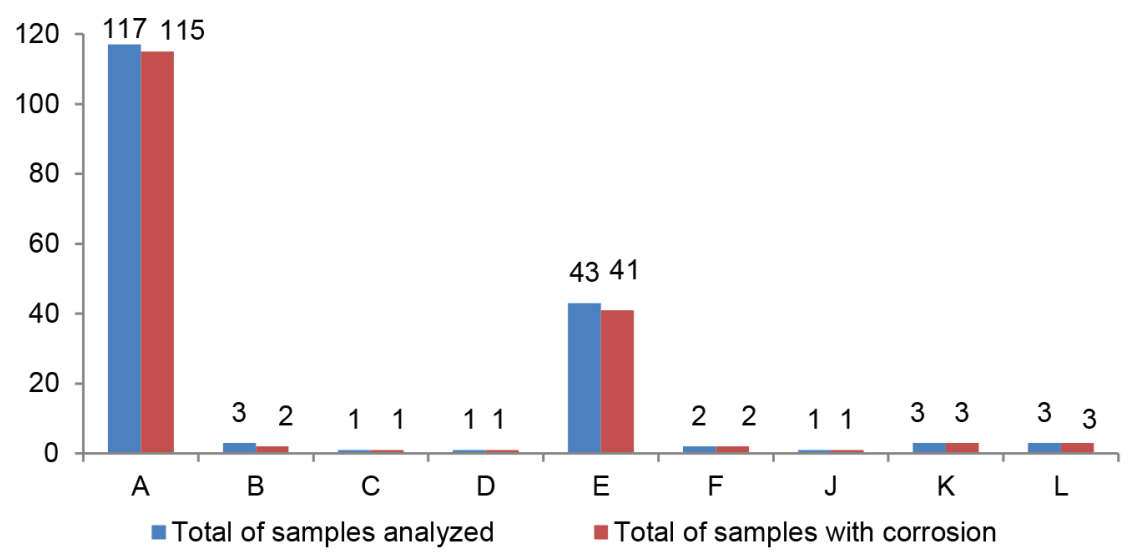

GRAPH 1 - Number of analyzed samples $(\mathrm{N}=174)$ and with corrosion $(\mathrm{N}=169)$ per brand. 
largest number of samples analyzed in relation to the total samples, representing respectively $66.1 \%$ and $23.6 \%$ of reproved samples for presenting corrosion. However, when analyzing the brands isolated, it is possible to verify that C, D, F, J, K and L brands presented corrosion in 100\% of the analyzed samples and $\mathrm{A}$ and $\mathrm{E}$ brands presented corrosion in $98.3 \%$ and $95.3 \%$, respectively.

These figures are alarming, considering that the needle is an invasive product and the presence of corrosion, besides not being in accordance with the requirements of the regulations that recommend quality and safety, exposes the patient to the fragility of the mechanical product and allergic or toxic reactions (Brasil, 2001; Inmetro, 2009). It is important to point out that the hypodermic needles are used on a large scale in units of medical and hospital care, both in the public system, and private, and the presence of deviations in quality, can impact on the population's health.

The corrosive environment can result in local attack which enhances the effect of various imperfections. The corrosive attack is influenced by the type of solution, its $\mathrm{pH}$, oxygen concentration and temperature. The 174 samples of hypodermic needles analyzed by the cannula resistance test to corrosion using immersion in a solution of sodium chloride, as in the citric acid solution, showed the same results, when observed with the support of an amplified view in up to 7 times. This is the result of electrochemical attack, because just like the chloride anions, the citric acid attacks the passive film that protects the steel, making them susceptible to corrosive action; or it may be from the productive process of the cannula's manufacturing (Inmetro, 2015).

Corrosion rate and corrosion damage can be assessed by observing the loss of mechanical properties and appearance, as the presence of spots and discoloration are visible examples of corrosion. Due to practicality, the American Society for Testing and Materials (ASTM) has defined general guidelines for assessing the extent of corrosion through visual assessment, which has been adapted for this study (Akazawa et al., 2005; FeitozaSilva et al., 2016).

Based on the macroscopic findings of the surface of the cannula, the results were classified into three categories (Table III), which gave a better characterization of the level of corrosive damage. Thus, in the current study, the extent of the cannula's corrosion was visually examined with the support of a magnification of up to 7 times and classified from 0 to 2 , based on macroscopic findings.

It is important to note that 174 batches were analyzed, being that in this test, 5 units of needles were used; therefore, a total of 870 needles were analyzed. The three main observations found were excess of silicone, texture difference and wear, both in relation to the number of samples and the number of needles analyzed.

The degree 0 (Figure 2) was defined as no sign of corrosion, but it comprises the presence of excess of silicone (Figure 2A) and markings identified as ring (Figure 2B). The excess of silicone consists of the presence of drops or threads of hardened silicone on the cannula surface (Figure 2A). As observed in Table III, 83.3\% of the samples showed excess of silicone in at least one of the units studied.

It may be necessary to lubricate the hypodermic needles to facilitate the introduction; however this lubrication must not be visible, because the presence of drops of silicone can lead to clogging of the needle during the application of the product to be injected (ABNT, 2010; Brasil, 2011; Iartelli, 2015). With the blockage,

TABLE III - Observation found in the cannula

\begin{tabular}{lcccc}
\hline Observations & $\mathbf{N}^{\mathbf{0}}$ of Batches & $\mathbf{\%}$ & $\begin{array}{c}\mathbf{N}^{\mathbf{0}} \text { of Needles } \\
\text { Evaluated }\end{array}$ & $\mathbf{\%}$ \\
\hline Corrosion degree 0 & & & & 47.9 \\
$\quad$ Excess of silicone & 145 & 83.3 & 417 & 28.6 \\
$\quad \begin{array}{l}\text { Appearance of rings } \\
\text { Corrosion degree 1 }\end{array}$ & 107 & 61.5 & 249 & 36.2 \\
$\quad$ Symmetrical scratches & 103 & 59.2 & 315 & 21.0 \\
$\quad$ Stains or difference in coloring & 84 & 48.3 & 183 & 47.8 \\
Corrosion degree 2 & & & & 8.9 \\
$\quad$ Texture difference & 138 & 79.3 & 416 & 37.2 \\
$\quad$ Black dots & 54 & 31.0 & 77 & 324 \\
$\quad$ Wear & 109 & 62.6 & & \\
\hline
\end{tabular}


there is the risk of an injury at the local of application, since the hardened silicone makes it difficult the needle's introduction. Besides, the excess of silicone can cause an allergic process to the user, because this substance can act as an allergen when it penetrates the skin and it can trigger an immune reaction of the organism (Inmetro, 2009; Morais et al, 2010). Therefore, despite not being a sign of corrosion, the presence of drops of silicone is nonconformity (Brasil, 2011).

The marking identified as a ring consists of circles of different texture and/or color present in the cannula (Figure 2B) and it was found in $61.5 \%$ of the samples analyzed (Table III, Figure 2). It was not possible to affirm that these markings are signs of corrosion, and they may be related to a failure in the production process and therefore, they deserve to be investigated later.

Degree 1 (Figure 3) consists of the initial stage of the corrosive damage, when the discoloration of the surface generally occurs. For this reason, it comprises the presence of symmetrical scratches (Figure 3A) and stains and the difference in the cannula coloring (Figure 3B).

Symmetrical scratches were found in $59.2 \%$ of the samples analyzed (Table III, Figure 3). During the production process, the cannulas are subjected to a bath in a solution containing acid, which generates small cracks in the surface of the cannula for the silicone deposition (Iartelli, 2015). Although a feature of the manufacturing process, the amount of scratches present on the surface of the cannula resulted in a light alteration of the cannula texture, and this result was considered as degree 1 .

Presence of spots and color difference (Figure 3B) was observed in $48.3 \%$ of the samples (Table III, Figure $3)$. These changes in the surface of the cannula may be the result of the attack promoted by immersion in corrosive solution or from the needle manufacturing process, regardless of the nature of the steel used. However, according to the normative references, this represents nonconformity and therefore, should not be found in the product (Brasil, 2011; Inmetro, 2009).

Grade 2 (Figure 4) involves a superficial loss of metal and consists of the difference of texture (Figure $4 \mathrm{~A}$ ), presence of black spots (Figure 4B) and wear on the surface of the cannula (Figure 4C).

The presence of texture differences was observed in $79.3 \%$ of the samples (Table III, Figure 4). This texture difference, characterized as roughness on the surface

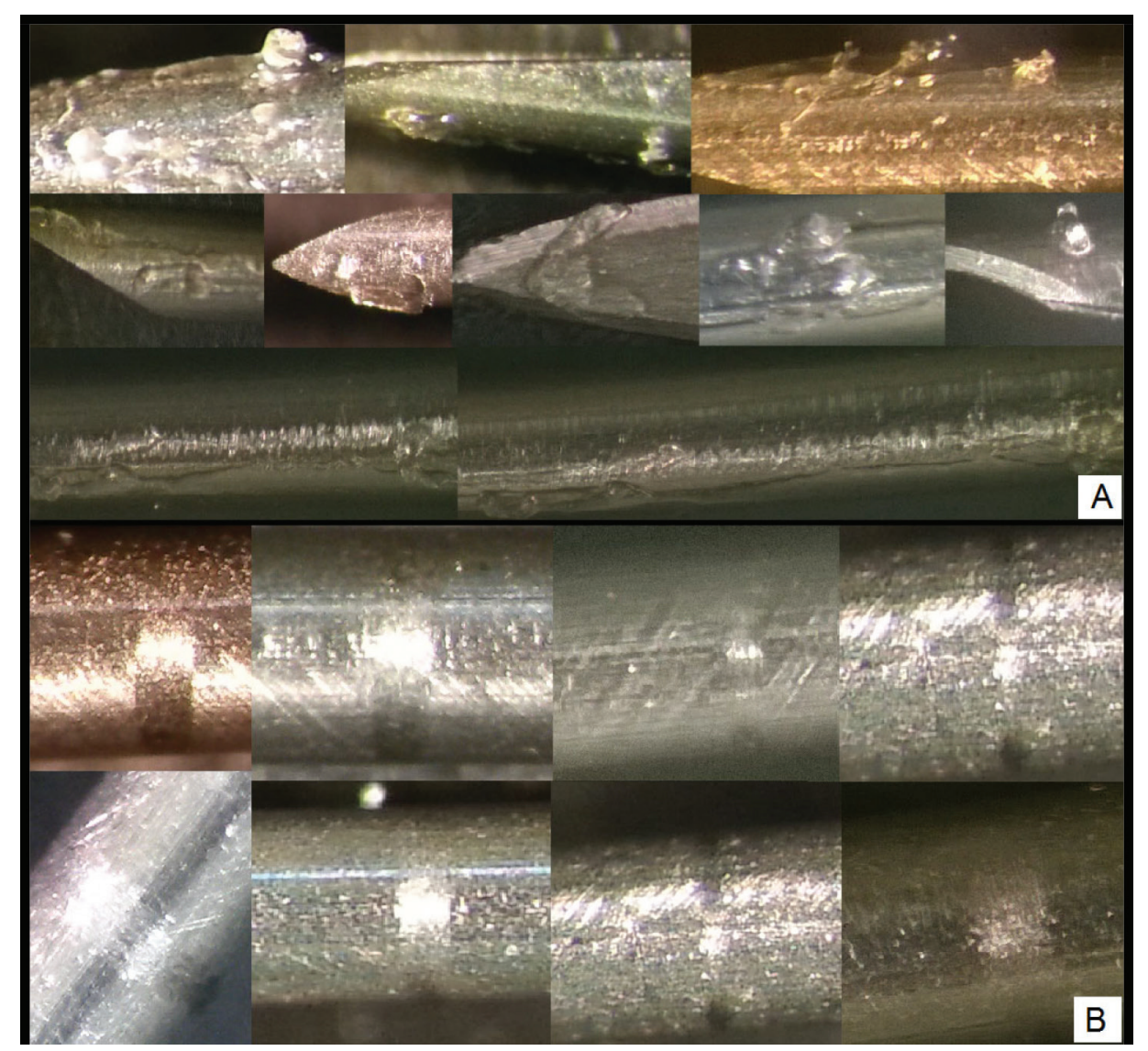

FIGURE 2 - Corrosion degree 0. 2A - Presence of excess of silicone. 2B - Circles of different texture and/or color present in the cannula. 


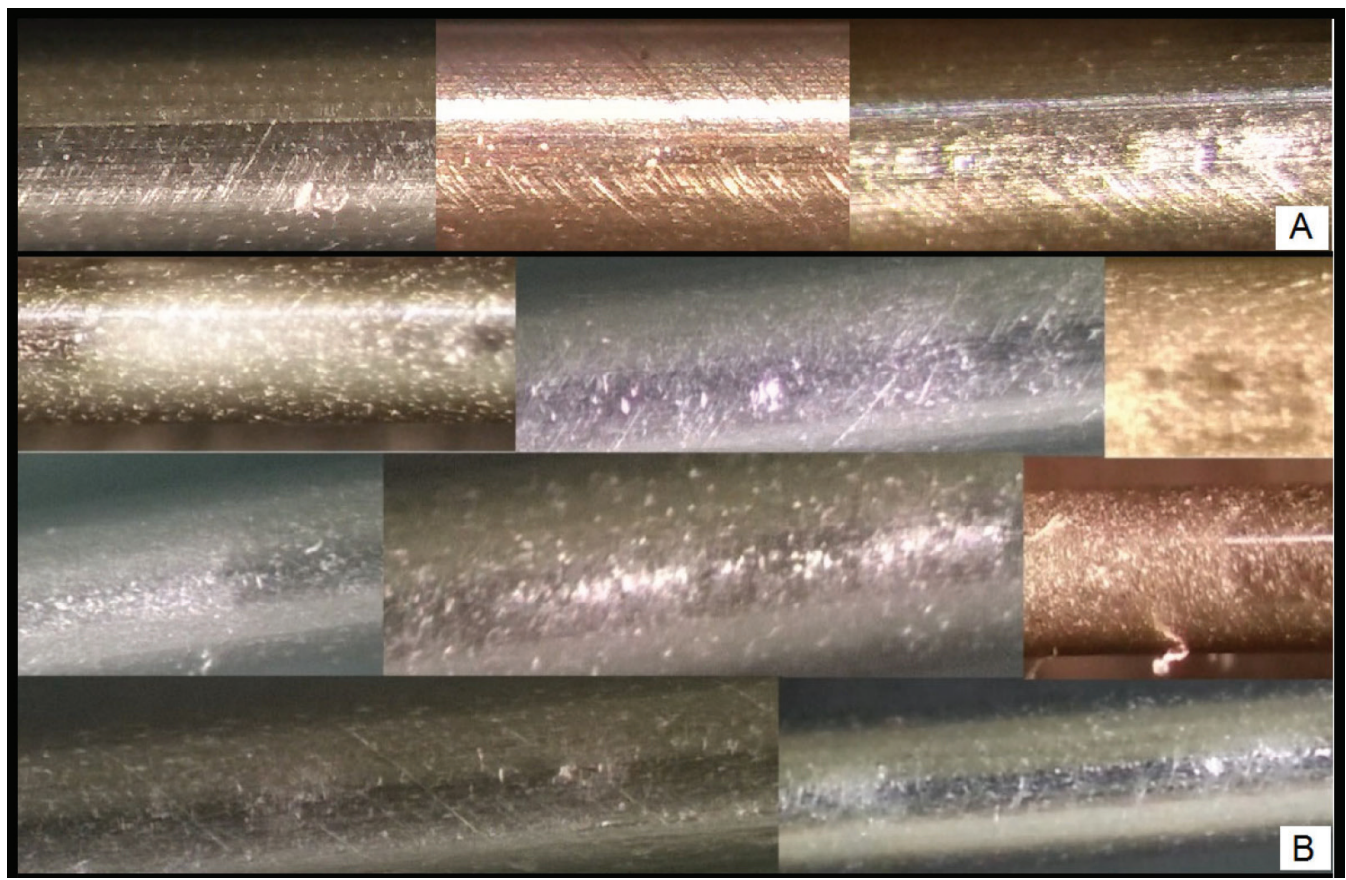

FIGURE 3 - Corrosion degree 1.3A - Symmetrical scratches in hypodermic needles. 3B - Stains and difference in coloring on the hypodermic needle cannula.

of the cannula (Figure 4A), may be from the needle manufacturing process or related to the steel used, and this result was considered as grade 2, as it involves a loss of metal from the surface of the cannula, which can result in weakness and breakage (Brasil, 2011; Inmetro, 2009).
Black spots were found in $31 \%$ of the samples (Table III, Figure 4) and their presence is associated with corrosion of stainless steel, especially in solders or welding joints. There are also colored corrosion products due to the presence of nickel and chromium in the alloy. In addition, black dots may also be related to manufacturing

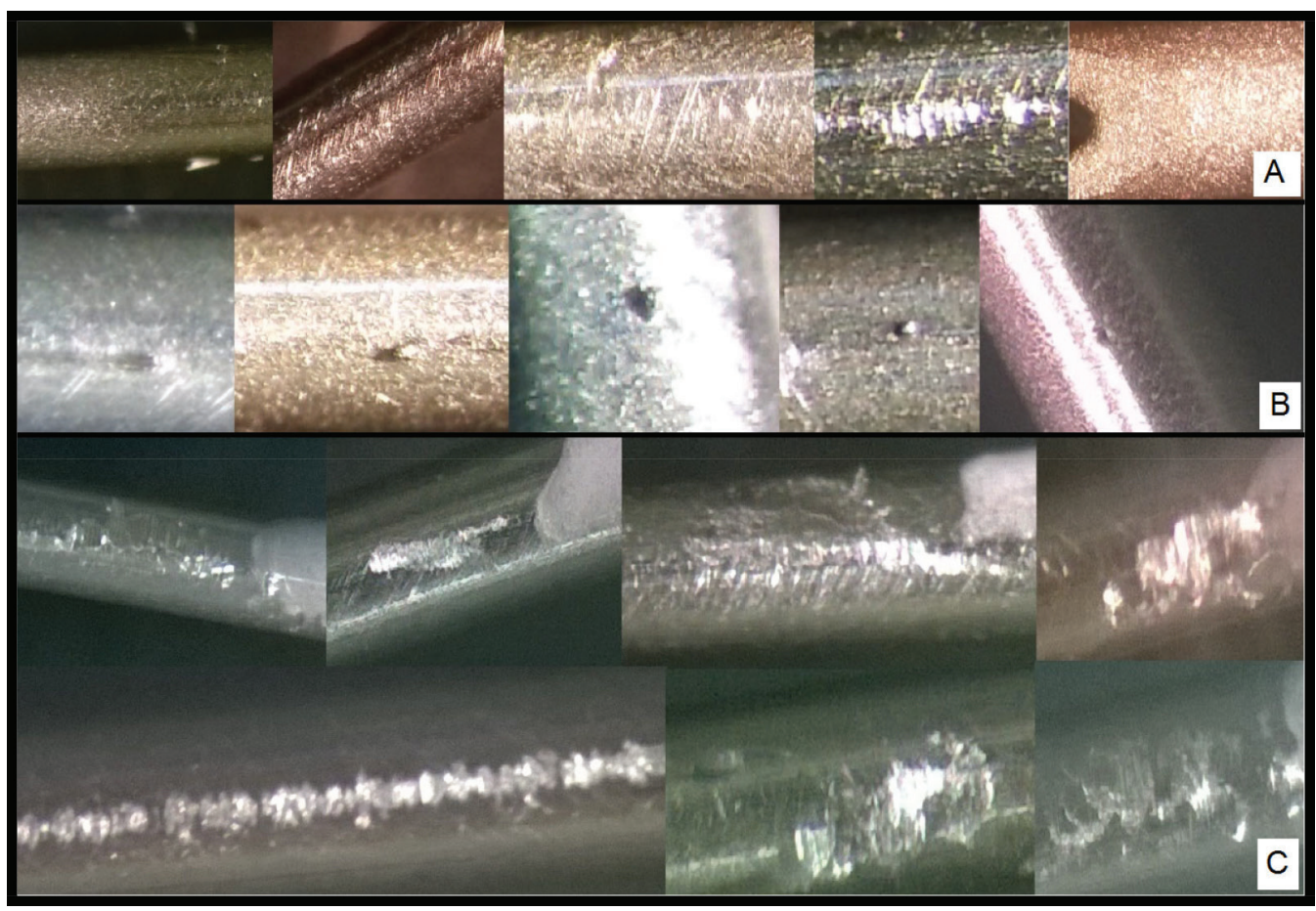

FIGURE 4 - Corrosion degree 2.4A - Black dots on the hypodermic needle cannula. 4B - Wear on the hypodermic needle cannula. $4 \mathrm{C}$ - Difference of texture on the hypodermic needle cannula. 
defects, called "GOUGE", that occur during drawing (Bagatin et al, 2011; Iartelli, 2015).

Wear was found in $62.6 \%$ of the batches (Table III, Figure 4) and consists of a corrosion process located mainly near to the welding joints. This observation results in the weakness of the needle and greater release of metallic ions, and it is necessary to reduce the deterioration of the welding regions, making the use of needles safer in relation to the breakage and the sensitivity of the patients to nickel (Bagatin et al, 2011).

\section{CONCLUSIONS}

The samples evaluated in this study were sent by 18 of the 27 federative units of Brazil, showing great representativeness. The presence of the Inmetro seal in all batches evaluated allowed to treat the samples in an equivalent way, since all were submitted to the current legislation.

The performance of the visual test using magnifying glass (increase of up to 7 times) was the differentiating fact, causing a total inversion of the results, that is, products were satisfactory for consumption, passing to a majority of products (failure of $97.1 \%$ of samples of hypodermic needles analyzed). Thus, when comparing the results obtained through these two methodologies, it was possible to observe the corrosive damages present in the cannulas when the visual test with magnification was used. The most current standard (observation without increase) is much less stringent than the old one. All the needles analyzed by ABNT NBR ISO 9626:2003 methodology were considered to be in good compliance, that is, they present the desired quality. However, when analyzed by ABNT NBR 9259:1997 methodology, the unsatisfactory index was $97.1 \%$ (169 samples in 174 were rejected) in the cannula corrosion resistance test, that is, inadequate for the consumption of the population.

The results showed that there is a weakness in the methodology recommended by the current norm (9626:2003) and also that the extended view related to the repealed norm (NBR 9259:1997) would allow to evaluate defects and deviations of quality that can impact the health of the population, especially when we think of critically ill patients, such as immunosuppressed, newborns and the elderly.

This comparative study completely changes the results of compliance and quality, leads us to rethink the importance of compulsory certification for health surveillance and should generate a reflection of the regulators.

Metrological certification is only one of the tools for the health system, although it is a worldwide trend to believe that certification guarantees the quality of a product.

In Brazil, products with compulsory certification are increasing. However, compliance with health standards and quality has different objectives and are regulated in Brazil by different institutions.

Therefore, certification does not guarantee quality and reiterates the importance of monitoring with laboratory quality control. Continuous monitoring should be carried out by the network of modernized and qualified public health laboratories, also meeting this specificity.

\section{ACKNOWLEDGMENTS}

Juliana Machado, Chemistry Department, INCQS/ Fiocruz.

This study was financed in part by the Coordenação de Aperfeiçoamento de Pessoal de Nível Superior - Brasil (CAPES) - Finance Code 001

\section{REFERENCES}

Akazawa T, Minami S, Takahashi K, Hotani T, Hanawa T, Moriya H. Corrosion of spinal implants retrieved from patients with scoliosis. J Orthop Sci. 2005;10(2):200-5.

ABNT. Associação Brasileira de Normas Técnicas. NBR 9259: Agulha hipodérmica estéril e de uso único. Rio de Janeiro: ABNT; 1997.

ABNT. Associação Brasileira de Normas Técnicas. NBR ISO 9626: Tubo para agulha de aço inoxidável para fabricação de dispositivos médicos. Rio de Janeiro: ABNT; 2003.

ABNT. Associação Brasileira de Normas Técnicas. NBR ISO 7864: Agulha hipodérmica estéril e de uso único. Rio de Janeiro: ABNT; 2010.

ABNT. Associação Brasileira de Normas Técnicas. NBR 5601: Aços inoxidáveis classificação por composição química. Rio de Janeiro: ABNT; 2011.

Bagatin CR, Ito IY, Andrucioli MCD, Nelson-Filho P, Ferreira JTL. Corrosion in Haas expanders with and without use of an antimicrobial agent: an in situ study. J Appl Oral Sci. 2011;19(6):662-7. 
Brasil. Resolução RDC n.185, de 22 de outubro de 2001. Aprova o Regulamento Técnico que consta no anexo desta Resolução, que trata do registro, alteração, revalidação e cancelamento do registro de produtos médicos na Agência Nacional de Vigilância Sanitária. [cited at 2015 Set, 02] Available from: http://www. anvisa.gov.br/anvisalegis/resol/2001/185_01rdc.htm.

Brasil. Ministério da Saúde. Secretaria de Atenção à Saúde. Departamento de Atenção Básica. HIV/Aids, hepatites e outras DST / Ministério da Saúde, Secretaria de Atenção à Saúde, Departamento de Atenção Básica. Brasília: Ministério da Saúde; 2006.

Brasil. Resolução RDC n.5, de 4 de fevereiro de 2011. Estabelece os requisitos mínimos de identidade e qualidade para as agulhas hipodérmicas e agulhas gengivais. Diário Oficial da União. n.26, 7 fev. 2011. Seção1, p.69.

Carbó HM. Aço inoxidável: aplicações e especificação. Associação Brasileira do Aço Inox. 2001. [Cited at 2015 Nov. 12] Available from: http://www.rioinox.com/Acesita_Aplica Especifica.pdf.

Feitoza-Silva M, Fernandes BS, Carvalho SFR, Carvalho CM, Vale RFD, Nobre PFS et al. Certificação compulsória e qualidade da agulhas e seringas em um Hospital Sentinela. Visa Debate. 2016;4(2):21-6.

Giordani EJ, Ferreira I, Balancin O. Propriedades mecânicas e de corrosão de dois aços inoxidáveis austeníticos utilizados na fabricação de implantes ortopédicos. Rev Escola Minas. 2007, 60(1):55-62.

Girotto MA, Volpato MC, Ranali J. Avaliação da padronização de agulhas anestésicas odontológicas comercializadas no Brasil. Pesqui Odontol Bras. 2000;14(3):294-9.
Iartelli A. Avaliação de defeitos tipo "GOUGE” em tubos de aço inox 3041 utilizados na fabricação de agulhas hipodérmicas. Contribuição técnica ao $12^{\circ}$ Seminário Brasileiro do Aço Inoxidável, parte integrante da ABM Week, Rio de Janeiro, 17 a 21 de agosto de 2015. [Cited at 2016 Jan. 02] Available from: http://www.abinox.org.br/upfiles/arquivos/inox-2015/ AVALIACAO-DE-DEFEITOS-TIPO-GOUGE.pdf.

Inmetro. Instituto Nacional de Metrologia. Programa de Análise de Produtos: Relatório sobre análise em seringas e agulhas hipodérmicas estéreis de uso único. 2009. [Cited at 2016 Jun. 02] Available from: http://www.inmetro.gov.br/consumidor/ produtos/seringas_agulhas.pdf.

Inmetro. Instituto Nacional de Metrologia. Portaria n.501, de 29 de dezembro de 2011. [Cited at 2016 Jun. 02] Available from: http://www.inmetro.gov.br/legislacao/rtac/pdf/RTAC001775. pdf.

Inmetro. Instituto Nacional de Metrologia. Avaliação da conformidade. $6^{a}$ ed. 2015. [Cited at 2015 Nov. 12] Available from: http://www.inmetro.gov.br/qualidade/.

Morais LO, Vale RFD, Alcides APP, Silva, FSQ, Feitoza-Silva M. Avaliação de marcas comerciais de agulhas hipodérmicas através de teste de resistência à corrosão. Associação Brasileira do Aço Inox. 2010. [Cited at 2015 Set. 02] Available from: http:// www.arca.fiocruz.br/handle/icict/13964.

Tebecherani CTP. Aços inoxidáveis. [Cited at 2016 Jun. 02] Available from: http://www.pipesystem.com.br/Artigos Tecnicos/Aco_Inox/body_aco_inox.html.

Received for publication on $01^{\text {st }}$ March 2018 Accepted for publication on $09^{\text {th }}$ August 2018 